\title{
APRENDIZAJE COOPERATIVO Y EVALUACIÓN DE HABILIDADES SOCIALES
}

\author{
Cadoche, L. ${ }^{1 ;}$ Tomatis, J. P. ${ }^{1} \&$ Frank, F. ${ }^{1}$
}

\begin{abstract}
RESUMEN
En la cátedra de Matemática de Ciencias Veterinarias de la Universidad Nacional del Litoral estamos trabajando en el sistema de Aprendizaje Cooperativo. Éste no es sólo un método de enseñanza y aprendizaje, es una concepción diferente de este proceso. La meta que se propone es conseguir que los alumnos aprendan sintiéndose comprometidos con el aprendizaje de sus compañeros. Para ponerlo en práctica organizamos a los alumnos para que trabajen en grupos y dentro del aula valoramos, incentivamos y practicamos habilidades sociales, cognitivas, de comunicación o relación interpersonal, y de actuación o inserción social.

Con esta metodología de trabajo apostamos por una concepción global de la persona, priorizando su formación integral como sujeto social activo, comprometido con su entorno, solidario y preparado para afrontar las exigencias del mundo actual.

Palabras clave: Aprendizaje cooperativo, habilidades sociales, interdependencia positiva, evaluación integral.
\end{abstract}

\section{SUMMARY}

\section{Cooperative learning and evaluation of social skills}

In mathematics of Veterinary Sciences of the Universidad Nacional del Litoral are working in the system of Cooperative Learning. This is not only a method of teaching and learning, it is a different conception of this process. The goal that is proposed is to ensure that students learn and feel committed to the learning of their peers. To put it into practice we organize the students to work in groups and in the classroom we appreciate, encourage and practice social and cognitive skills, communication and interpersonal relationship, and performance of social integration. With this methodology of work we hope for an inclusive vision of the person, prioritizing his integral formation as a social subject, active and committed with his environment, united and ready to handle the demands of today's world.

Key words: Cooperative learning, social skills, positive interdependence, integral evaluation.

1.- Facultad de Ciencias Veterinarias, Universidad Nacional del Litoral. Kreder 2805, (3080) Esperanza, provincia de Santa Fe. Telefax: (03496) 420639.

Manuscrito recibido el 12 de diciembre de 2007 y aceptado para su publicación el 27 de diciembre de 2007. 